\title{
The Concept of Race in International Criminal Law
}

The Nazis defined the Jews as a race inferior to the Aryan race, the Khmer Rouge identified the 'new people' as enemies with a biologically dissimilar essence, and in Darfur (Sudan), the Janjaweed militia labelled their enemies derogatorily as 'Zourga', or black Africans. Seemingly, these victim classifications all have a racial denominator in common. Yet, how does international criminal law in general and the law of genocide in particular define race? Is it even possible to define race?

In its early years, the International Criminal Tribunal for Rwanda (ICTR) interpreted the protected groups of genocide, including the racial group, in a purely objective manner. In doing so, the tribunal disrespected two important facts: first, according to natural sciences, humankind cannot be meaningfully divided into objectively/biologically distinct races. Second, the process leading up to a genocide is symptomatically subjective: in the perpetrator's eyes, the victim group is immutably different from the perpetrator's ostensibly superior group. In this process of so-called 'othering', a dichotomy between 'us' and 'them' is created. The marginalized 'other' group can, notably, have an imagined identity, entirely dependent on the perpetrator's perceptions. As such, the victim group ought to be constructed purely subjectively, based upon the perpetrator's understanding of the victims' (racial) otherness.

\section{Race in the Jurisprudence of the International Criminal Tribunals}

The ICTR Akayesu trial judgment of 1998 was the first ever conviction for the crime of genocide by an international criminal tribunal. "The conventional definition of racial group," Akayesu held, "is based on the hereditary physical traits often identified with a geographical region, irrespective of linguistic, cultural, national or religious factors" (see para. 514). The Trial Chamber did not provide any supporting evidence, legal or extra-legal, to substantiate this definition. The reference to 'hereditary physical traits' implies an objective approach to a scientifically highly disputed method, namely the identification of people by means of their physical appearance, such as their skin color. Hereditary is defined as "genetically transmitted or transmittable from parent to offspring". Defining race as the genetic transmission of physical traits is not only scientifically wrong, it also preserves outdated and contentious methods of classifying people.

Later judgments of the different international criminal tribunals and courts have gradually moved away from the objective definition of the Akayesu trial judgment. Yet, they have never fully endorsed a subjective, perpetrator-based approach to defining the protected groups of genocide. Thereby, they fail to recognize the inherent subjectivity of a (pre-)genocidal process. Rather than attempting to objectively construct distinct racial groups for the purpose of international criminal law, judges should consider the perpetrator's inner thoughts. The legal requirement of "the intent to destroy, in whole or in part, a (...) racial group, as such" (Art. 2 Convention on the Prevention and Punishment of the Crime of Genocide; verbatim definition in the statutes of the ad hoc tribunals and the Rome Statute of the International Criminal Court), connects the perpetrator's intent with the victim group definition. Thus, the proof of the perpetrator's dolus specialis comprises the definition of the protected racial group. 


\section{Legal Objectivity vs. Subjective Classification}

Notions like 'race' are difficult to grasp because they are social constructs rather than objective, verifiable facts. Since much of our (legal) worldview depends on understanding objectivity, the contrast between such objective and subjective realities is further exacerbated. The law of genocide puts four categories at the disposal of the courts: the national, ethnical, racial or religious group. Each category is an analytical tool, which they can use to extrapolate to individual victims the purported characteristic of an imagined archetypal 'racial' group member. However, the assignment of victims to one of the four groups cannot signify that they exist in reality, but rather that the perpetrators - and consequently the judges - assume they do. The legal classification is treated as a reality, although it actually originates in the perception of the perpetrator. Thus, rather than looking for an objective legal reality of 'race', the victim group's imagined identity based on the perpetrator's perception should be the point of departure for a legal classification of the victims.

\section{The Legal Relevance of Othering}

Prior to any genocide, commonalities between 'us' and 'them' are removed. Instead, dissimilarities are enhanced, often by means of communication, to the point where the perpetrator calls for the extermination of the 'others'. Communication is here understood broadly to include any kind of utterances by the perpetrator that reveal his perception of the victim group. While social sciences have long recognized the importance of the process of othering, in which a group of 'others' is identified, stigmatized, discriminated, and finally dehumanized, it is rarely discussed in judgments or legal scholarship.

Dehumanization is inherent to any genocidal process and abolishes all humanness from the victims, who therefore are not one of 'us'. Dehumanization is a belief, a way of thinking, according to which some human beings only give the impression of being human. Beneath the surface, however, they are not human after all. Thus, albeit having a human appearance, these dehumanized beings, in the understanding of the perpetrator, consist of an inhuman essence or, put differently, of a racial otherness. Indeed, research suggests that biologically grounded racethinking is present prior to any instance of mass atrocity (see e.g. Paul Taylor, p. 8; David Livingstone Smith, p. 163, Nigel Eltringham, pp. 5-12; Stephan Cornell and Douglas Hartmann, p. 28). It is important to note that the victim group's dehumanization alone will not lead to genocide. Rather, the mortal threat the victims' out-group allegedly presents to the perpetrator's in-group is what ultimately distinguishes genocide from other discrimination or inhumane treatment.

Commonly, the perpetrators distinguish their victims by some stigma or myth and refer to them by humiliating metaphors, a treatment they believe to be fully justified. Such ideology is then spread by propaganda that defines the victim as outside the pale of human existence and therefore susceptible to attack. The vital communication aspect by which 'the others' are first identified, portrayed as a ubiquitous threat and then targeted as victims of genocide, is acknowledged by several scholars. 
Degrading epithets like cockroach, maggot, savages, vermin, and disease (cancer, plague) deny the victims' humanity. The dehumanization of the victim group is usually necessary for the perpetrator to overcome the typical human disgust against the violence. In a genocide trial, dehumanizing communication in the shape of speeches, statements, utterances, (written) orders, and publications can all become proof of the perpetrator's dolus specialis.

\section{Conclusion}

International criminal law defines against whom the crime of genocide can be committed and, conversely, who faces punishment for committing it. Apart from genocide, international law protects members of racial groups also from the crimes against humanity of persecution and apartheid. Since 'race' is part and parcel of the definition of three international crimes, its contemporary legal interpretation and a coherent judicial approach to it remain imperative.

In sum, what is the definition of race in international criminal law? In my view, race ought to be defined by means of a subjective, perpetrator-based approach. The perpetrator's (objectively) observable demeaning and dehumanizing behavior reveals his or her understanding of the victims. As such, 'race' becomes a matter of proof: if the perpetrator perceives the victims as members of a different (and, typically, an inferior) racial group and manifests this understanding through his or her behavior, the perpetrator can be found guilty for committing the crime of genocide against a racial group.

Carola Lingaas from the University of Oslo (Norway) defended her $\mathrm{PhD}$ thesis on 'The Concept of Race in International Criminal Law' in November 2017, in which she analyzes the crimes of genocide, persecution, and apartheid. Prior to taking up her position as a doctoral research fellow, she worked in different positions in the Red Cross. She earned her master's degree from the University of Zürich (Switzerland) and an LL.M. in Public International Law from the University of Oslo. 